\title{
Utilization of Waste Glass Powder and Glass Composite Fillers in Asphalt Pavements
}

\author{
Jayvant Choudhary $\mathbb{D}^{1},{ }^{1}$ Brind Kumar $\mathbb{D}^{\circ},{ }^{2}$ and Ankit Gupta $\mathbb{D}^{2}$ \\ ${ }^{1}$ Department of Civil Engineering, Madhav Institute of Technology and Science, Gwalior, India \\ ${ }^{2}$ Department of Civil Engineering, Indian Institute of Technology (Banaras Hindu University), Varanasi, India
}

Correspondence should be addressed to Ankit Gupta; ankit.civ@iitbhu.ac.in

Received 22 April 2021; Revised 31 August 2021; Accepted 21 September 2021; Published 13 October 2021

Academic Editor: Guoyang Lu

Copyright ( $) 2021$ Jayvant Choudhary et al. This is an open access article distributed under the Creative Commons Attribution License, which permits unrestricted use, distribution, and reproduction in any medium, provided the original work is properly cited.

\begin{abstract}
Today, researchers around the globe are looking for suitable alternatives of conventional fillers which can form flexible pavements with satisfactory engineering performance in an environmental friendly and cost-effective manner. This study investigated the engineering, economical, and environmental viability of recycling waste glass powder (GP) and glass-hydrated lime (GL) composite as alternative fillers, in place of stone dust (SD). All fillers were characterized, and asphalt concrete mixes incorporating them at different proportions (4-8.5\%) were designed using the Marshall mix design method. The engineering performance of asphalt mixes was analyzed using the static creep analysis, indirect tensile fatigue test, Cantabro test, modified Lottman test, resilient modulus test, mixing time analysis, and boiling water test. Additionally, the design of single km of two-lane flexible pavements utilizing aforesaid mixes was done as per the mechanistically empirical method suggested in IRC 37 guideline. Finally, the economic and environmental analysis was done by comparing their material cost and global warming potential (GWP). GL and GP mixes exhibited better resistance against rutting, fatigue, and low temperature cracking at lower optimum asphalt content than SD mixes. However, GP mixes also displayed poor moisture resistance and adhesion due to the high amount of silica in GP. GL mixes had satisfactory moisture resistance up to 7\% filler content due to the fine nature and anti-stripping properties of hydrated lime. The pavement containing GL and GP fillers also reduced material cost and GWP up to $35 \%$ while consuming up to 74 tons of GP.
\end{abstract}

\section{Introduction}

In recent years, reclaim, reuse, and recycling of wastes in place of virgin materials have become a recurring theme of growing importance. Transportation infrastructures play a key role in this context, as any new construction or rehabilitation consumes a huge amount of natural materials [1]. Utilization of wastes as alternative to virgin materials solves two important issues: the issues regarding the ecofriendly disposal of wastes as well as fulfilling the need to find suitable alternative to conventional/virgin materials. Global pavement network majorly consists of flexible pavements which use asphalt concrete mixes as their surface and base courses. Asphalt mix is a heterogeneous multiphase material which primarily comprises aggregates of various shapes and sizes, asphalt binder, and filler. Asphalt mixes are extensively adopted in flexible pavements around the world as surface and binder courses which are with the combination of aggregates and asphalt binder. Various sizes of mineral aggregates in the asphalt mixes make up a rigid skeleton while the asphalt binder behaves as an adhesive. The aggregate portion which passes through the No. 200 sieve $(75 \mu \mathrm{m})$ is termed as filler, which influences the mechanical behavior and durability of the asphalt mix [2-4]. The filler present in the asphalt mix combines with asphalt binder to form asphalt mastic. The filler activity in the mastic is due to the physical hardening and chemical interaction [5]. Based on this activity, the fillers can be generally classified into two categories known as active fillers and passive (inert) fillers. The fillers which 
exhibit chemical activity in the mastic due to their alkaline nature and acidic nature of binder are termed as active fillers [5-7]. This chemical reaction is reported to improve the anti-aging potential, adhesion, and high temperature resistance in asphalt mastic and mixes [7, 8]. It is majorly dependent on the compositional and elemental characteristics of filler and binder. The fillers such as hydrated lime, cement, steel slag, and so on fall under the category of active fillers. On the other hand, the inert or passive fillers exhibit little to no chemical activity in asphalt mastic. However, they are usually responsible for causing stiffness or physical hardening in the asphalt mastic owing to their physical characteristics. The fillers such as stone dust, limestone, and granite fall in the category of passive fillers [9]. Overall, the performance of asphalt mixes against distresses like permanent deformation, load and non-load dependent cracking, aging, and moisture sensitivity is largely dependent on the physical and chemical characteristics of fillers $[3,10-12]$. Hence, it can be said that nature and quantity of fillers are essential to ensure the cost effectiveness and long-lasting performance of flexible pavements. The cement, stone dust, and lime are primarily used as conventional fillers. However, various agencies are promoting the utilization of waste and secondary byproducts in place of conventional materials not only to reduce landfill waste and to save the cost of conventional materials but also to ensure sustainable pavement construction by limiting the amount of greenhouse gas emission. It is essential that the asphalt mixes made with alternative materials should exhibit satisfactory engineering performance in a cost-effective and environmental friendly manner. The enhanced performance of asphalt mixes containing alternative solid waste fillers such as bauxite residue [13]; biomass ashes [14]; brick dust [15]; coal fly ash [16, 17]; and lime kiln dust [18] as fillers has inspired researchers to investigate the viability of other wastes to form technically, economically, and environmentally feasible flexible pavements. However, majority of the available studies are concerned with the examining the engineering performance of asphalt mix and very limited attention has been given in analyzing the material cost and environmental suitability of asphalt pavements made with these mixes.

Glass is one of the primarily used commodities which have numerous applications such as utensils, lighting, window shelves, flooring, appliances, solar panel, and fibre optic cables. The disposal of waste glass has become a primary environmental concern due to growing demand for landfill spaces and increasing emphasis on carbon footprint reduction of construction industries. Glass is a non-biodegradable material due to its inert nature. Non-recyclable waste glass takes around 1 million years to decompose and occupies precious landfill spaces. The waste glass disposal has emerged as a primary environmental concern due to the growing demand for landfill spaces and increasing emphasis on carbon footprint reduction of construction industries. Glass is one of the widely used materials whose annual global production is estimated to exceed 130 million tons [19]. Waste glass is usually referred to as a by-product of crushed bottles, window panes, and other glass items obtained from streams of industrial and municipal wastes. However, a significant quantity of waste is also obtained as waste slurry which is produced during cutting and polishing operations of glass slabs in glass industries [20]. Recently, waste glass has been successfully utilized in manufacturing products like cementitious binding material [21], acid resistant concrete [22], pavement base course [23], geopolymers [24], and ceramics [25]. However, there are only a few studies which have attempted to recycle the crushed glass and glass powder as aggregates (fine and coarse) and filler in asphalt mixes, respectively. Earlier studies [26, 27] have observed that the incorporation of glass powder in different quantities as filler led to the formation of asphalt mixes with higher Marshall stability in comparison to the asphalt mixes containing conventional fillers like cement and limestone dust. Arabani et al. [15] observed that the asphalt mixes containing glass powder as filler exhibited superior Marshall stability and rutting and fatigue resistance than conventional asphalt mixes. They concluded that the physical and chemical characteristics of glass powder filler are responsible for its better physicochemical interaction with asphalt binder that ultimately improved the performance of their asphalt mixes.

Simone et al. [28] also observed that incorporation of glass powder as filler increased the stiffness of asphalt mastics which may result in formation of asphalt mixes having better bearing capacity and rutting resistance. However, despite the superior performance of asphalt mixes against rutting and cracking, a few recent studies [29-31] have reported the poor behavior of asphalt mixes containing glass powder against stripping and ravelling. This was attributed to low asphalt absorption by the glass and high silica content in its composition $[29,31,32]$. In order to establish glass as alternative filler, it is vital that the asphalt mixes made with it exhibit satisfactory moisture resistance. Hence, attempts are needed to be made to introduce glass powder along with an anti-stripping agent in the form of a composite filler to ensure satisfactory performance of the asphalt mixes against moisture resistance. However, the primary challenge in this approach is to identify the appropriate anti-stripping agent along with its optimum proportion in the composite filler.

Hydrated lime is a well-known anti-stripping agent used in reducing moisture damage (stripping). Hydrated lime not only strengthens the asphalt-aggregate bond but also reacts with the highly polar molecules in asphalt to form strong chemical bonds to reduce stripping. The addition of hydrated lime also stiffens the mix and reduces the stripping by increasing the mechanical strength of the asphalt-aggregate bond. Hence, the addition of a small amount of hydrated lime with glass powder can reduce the possibility of stripping and can increase the allowable percentage of glass in the mix. The hydrated lime addition improved mechanical properties of asphalt mix and its aging resistance [33]. Hence, hydrated lime could be admixed in an optimum amount to the glass powder to form a glass-hydrated lime composite filler which could form asphalt mixes with superior rutting and cracking resistance without compromising its moisture sensitivity. 
There are very limited studies which have utilized glass as a construction material along with hydrated lime. LachanceTremblay et al. [34] examined the effect of glass aggregate and hydrated lime content on linear viscoelastic (LVE) properties of asphalt mixes, and asphalt mixes containing glass aggregates were found to have lower stiffness values than conventional asphalt mixes (i.e., no glass aggregates). Raschia et al. [35] investigated the performance of glass filler alone and in combination with hydrated lime as composite filler in cold emulsion asphalt mixes. Results indicated that after the curing period of three days, mixes stabilized with glass powder were unable to reach satisfactory resilient modulus and mechanical performance due to the poor reactivity of the silica with the asphalt binder/water. On the other hand, the composite filler formed with glass and hydrated lime delivered better performances due to the reaction between silica and calcium hydroxide. In this study, the authors have performed the investigation herein described to fill the huge research gap by developing a glasshydrated lime composite filler and analyzing the engineering suitability of asphalt mixes containing glass powder and glass-hydrated lime composite (newly developed) fillers against conventional asphalt mixes containing stone dust filler. Additionally, this is the first study which has investigated the economical and environmental suitability of asphalt mixes containing glass powder and glass-hydrated lime composite mixes.

\section{Objectives and the Brief Outline of the Study}

The overall objective of this study is to maximize the utilization of waste glass powder (GP) in asphalt concrete mixes as filler without compromising with the engineering, economical, and environmental suitability of asphalt mixes. Previous literatures observed that the GP is notorious in causing stripping in asphalt mixes, and hence the GP is incorporated not only as filler but also in the form of glasshydrated lime composite (GL) filler. GL as filler was prepared with an intention of avoiding the possibility of formation of the moisture-sensitive mix due to high silica content in glass by adding a nominal amount of $\mathrm{HL}$ as an anti-stripping agent.

To achieve this objective, the study is divided into four parts: (1) prequalification assessment of glass powder (GP), hydrated lime (HL), and stone dust (SD) fillers; (2) design of asphalt mixtures containing GP, GL, and SD fillers at different quantities $(4,5.5,7$, and $8.5 \%$ by weight of asphalt mix); (3) evaluation of mechanical and durability performance of designed mixes with relevant static and dynamic tests; and (4) design and cost analysis of flexible pavements using MEPDG-based IITPAVE software utilizing designed mixes in the surface course. Waste glass powder was collected from dumping ground of glass factory, where it was generated as dried slurry. The GL filler was prepared by fixing the proportion of hydrated lime at $2 \%$ in the respective filler proportion of the mix (4-8.5\%) and assigning the balance part to GP. The maximum permissible limit of HL used in the asphalt mix is specified as $2 \%$ by Indian pavement design guidelines [4]. Hence, the proportion of hydrated lime is fixed at $2 \%$ in GL to envisage the maximum utilization of GP (as per the objective) without compromising the asphalt mix's moisture resistance. The asphalt mix design was done as per MS-2 specification [36]. The asphalt mixes were compared in aspects such as strength, volumetric properties, rutting, fatigue and low temperature cracking resistance, moisture sensitivity, ravelling resistance, resilient modulus, and active and passive adhesion as per relevant testing specifications. The design and cost analysis of flexible pavements utilizing the aforesaid mixes in their surface course was done with IITPAVE software according to Indian pavement design guideline IRC 37: 2018 [37]. The research methodology of the study is displayed in the form of flow chart as shown in Figure 1.

\section{Materials and Experimental Investigation}

3.1. Materials. Dolomite aggregates were utilized, and their characteristics are mentioned in Table 1. The design gradation for the preparation of the asphalt concrete is stated in Table 2.

VG 30 asphalt binder (synonymous to PG 76-XX binder), whose properties are mentioned in Table 1, was used in the study. SD and HL were collected locally from Varanasi city, while GP was procured from the glass factory's dump yard situated in Bhopal city, India.

3.2. Tests on Filler. Various characterization properties of fillers were obtained as per relevant specifications. Specific gravity was assessed according to ASTM D854-14 [38]. Particle size distribution curves of fillers was drawn with Malvern mastersizer, and fineness modulus (FM) and mean particle size $\left(D_{50}\right)$ were assessed. Scanning electron microscopy (SEM) analysis was performed to analyze the shape and texture of fillers. The German filler test was done to determine the porosity of fillers [39]. X-ray diffraction (XRD) analysis was done with a Rigaku benchtop XRD device to obtain the minerals in fillers. The harmful clay content was assessed as per EN 933-9 [40]. Finally, the relative affinity of fillers towards binder and water was compared by determining their hydrophilic coefficients as per JTG E42 [41] specification.

\subsection{Testing of Asphalt Concrete}

3.3.1. Marshall and Volumetric Properties. Asphalt mixes were designed as per Marshall mix design procedure, in which binder content corresponding to $4 \%$ air voids is considered as OAC $[4,42]$. The binder content was varied in the range of $4.5-6.5 \%$, and three specimens were prepared at each binder level, and a total of 240 specimens ( 5 binder contents $\times 4$ types of fillers $\times 4$ filler contents $\times 3$ replicates) were prepared for the determination of OAC. The gradation for the mix is chosen as per MoRTH specification as shown in Table 2, and filler content was varied between $4,5.5,7$, and $8.5 \%$ by the weight of the aggregates. The filler proportion was increased by reducing the fine aggregate proportions which help to maintain the chosen gradation. As stated in 


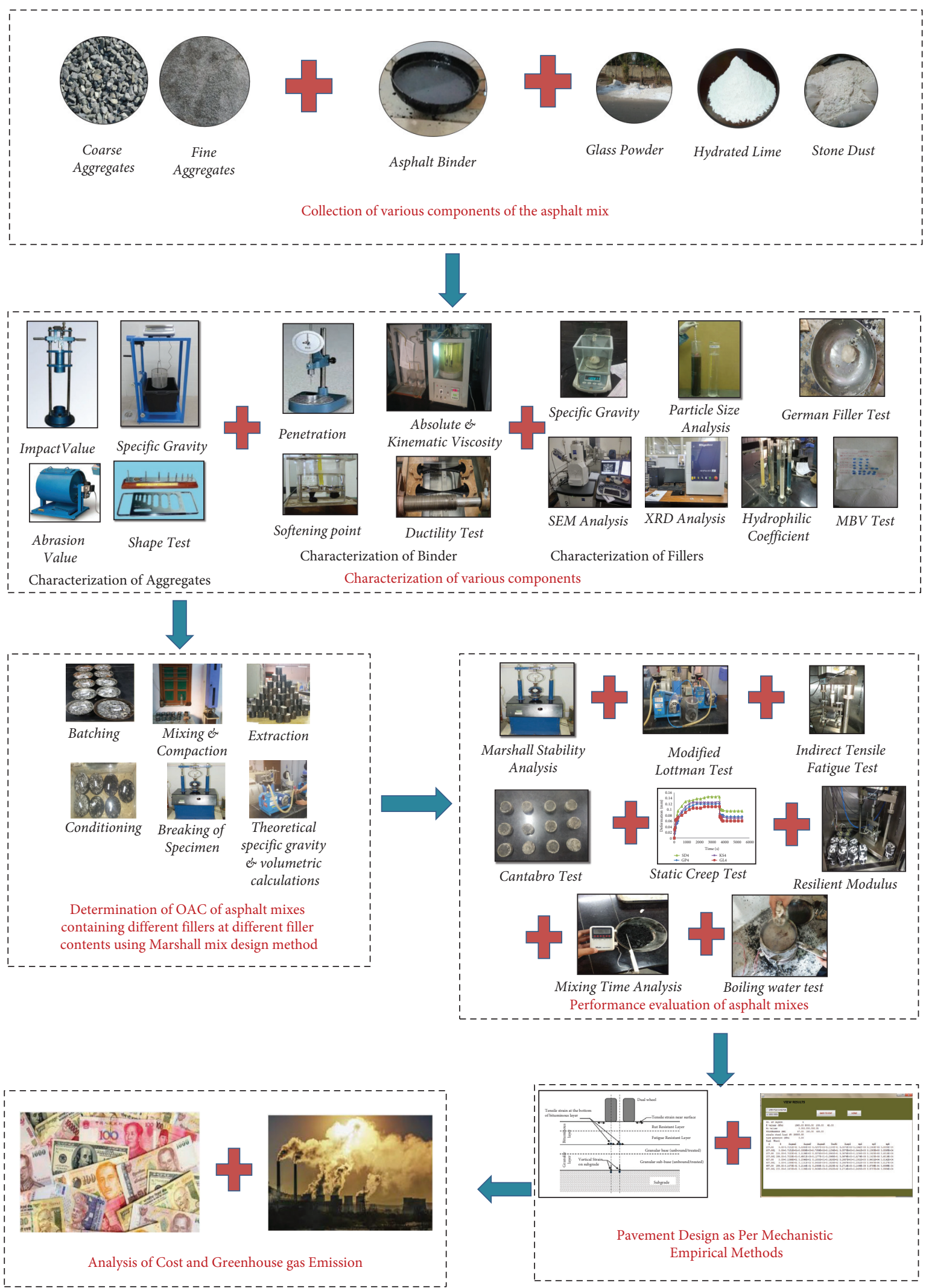

FIgURE 1: Flowchart showing entire research methodology of the study. 
TABLE 1: Properties of aggregate and asphalt.

\begin{tabular}{|c|c|c|c|c|}
\hline Material & Property & Specification & Results & Requirements \\
\hline \multirow{6}{*}{ Aggregates } & Bulk specific gravity of coarse aggregate & ASTM C127 & 2.795 & - \\
\hline & Bulk specific gravity of fine aggregate & ASTM C128 & 2.720 & - \\
\hline & Water absorption of coarse aggregate (\%) & ASTM C127 & 0.374 & $2 \%(\max )$ \\
\hline & Aggregate impact value (\%) & IS:2386 (Part IV) & $11.1 \%$ & $24 \%(\max )$ \\
\hline & Los Angeles abrasion value (\%) & IS:2386(Part IV) & $13.4 \%$ & $30 \%(\max )$ \\
\hline & Combined flakiness and elongation index & IS: 2386(Part I) & $21.3 \%$ & $35 \%(\max )$ \\
\hline \multirow{5}{*}{ Asphalt } & Absolute viscosity at $60^{\circ} \mathrm{C}$ (poise) & \multirow{5}{*}{ IS 73: 2013} & 2692 & $2400-3600$ \\
\hline & Penetration at $25^{\circ} \mathrm{C}(0.1 \mathrm{~mm})$ & & 62 & $50-70$ \\
\hline & Softening point ( $\underline{\mathrm{o}} \mathrm{C})$ & & 51.5 & $47(\min )$ \\
\hline & Ductility at $27^{\circ} \mathrm{C}(\mathrm{cm})$ & & $>100$ & $75(\min )$ \\
\hline & Specific gravity & & 0.999 & $0.98-1.04$ \\
\hline
\end{tabular}

TABle 2: Adopted gradation of asphalt concrete mix.

\begin{tabular}{lccccccccccc}
\hline Sieve sizes (mm) & 19 & 13.2 & 9.5 & 4.75 & 2.36 & 1.18 & 0.6 & 0.3 & 0.15 & 0.075 \\
\hline Allowable limits (\%) & 100 & $90-100$ & $70-88$ & $53-71$ & $42-58$ & $34-48$ & $26-38$ & $19-28$ & $12-20$ & $4-10$ \\
\hline Adopted gradation (\%) & 100 & 91 & 74 & 62 & 50 & 43 & 35 & 25 & 14 & $4,5.5,7$, and 8 \\
\hline
\end{tabular}

the previous section, asphalt concrete mixes incorporating GL filler were designed by replacing $2 \%$ GP at each filler dosage level with HL. The average Marshall (stability and flow) and volumetric properties (voids in mineral aggregates (VMA) and voids filled with binder (VFB)) of mixes were also determined at OAC. The three specimens were prepared at each $\mathrm{OAC}$, and a total of 48 specimens (4 types of fillers $\times 4$ filler contents $\times 1$ OAC $\times 3$ replicates) were prepared for the calculation of Marshall and volumetric properties, and average values are reported. The apparent film thickness (AFT) of mixes was estimated as per the following equation:

$$
\mathrm{AFT}=\frac{1000 V B E}{S_{s} P_{s} G_{m b}}
$$

where $S_{s}=$ specific surface of aggregates $\left(\mathrm{m}^{2} / \mathrm{kg}\right)$; $P_{s}=$ percentage of aggregates (\%); $G_{m b}=$ bulk specific gravity; and $V B E=$ effective asphalt content (\%)

3.3.2. Rutting Resistance. The rutting resistance was determined using a uniaxial static creep test. The testing was done as per BS 598-111 by imposing a static compressive load to specimen and determining its axial deformation with time [43]. The evaluation of the reversible part of deformation is determined by removing load and measuring the deformation recovered. The constant load was applied to the specimen to generate $100 \mathrm{kPa}$ axial stress during the loading period of 60 minutes, while the unloading period of the test is taken as 30 minutes. The three specimens were prepared at each OAC, and a total of 48 specimens ( 4 types of fillers $\times 4$ filler contents $\times 1 \mathrm{OAC} \times 3$ replicates) were prepared for the calculation of rutting resistance, and average values are reported.

3.3.3. Cracking Resistance. There are two primary types of cracking in asphalt mixes, namely, thermal cracking at low temperature and fatigue cracking. Cracking at low temperature is generated due to excessive tensile stresses generated in the mixes due to low temperature and embrittlement [44]. The low temperature cracking was determined at $0^{\circ} \mathrm{C}$ by calculating the indirect tensile strength (ITS) per ASTM D 6931-12 [45] specification. Higher ITS value corresponds to higher resistance to low temperature cracking and vice versa $[44,46]$.

Fatigue cracking is initiated at bottom of layer of asphalt mixes by the generation of tensile stresses due to repeated traffic loading at intermediate temperature [47]. The fatigue life of asphalt mixes was calculated as per EN 12697-24 guideline. The test was done at $25^{\circ} \mathrm{C}$ under controlled stress condition, and the testing stress is taken as $40 \%$ of the ITS. The haversine loading is applied through the haversine load pulse with loading period of $0.1 \mathrm{~s}$ and rest period of $0.4 \mathrm{~s}$. The three specimens were prepared at each OAC, and a total of 48 specimens ( 4 types of fillers $\times 4$ filler contents $\times 1$ OAC $\times 3$ replicates) were prepared for the calculation of low temperature cracking and fatigue resistance, and average values are reported.

\subsubsection{Asphalt Aggregate Adhesion and Moisture} Susceptibility. An asphalt mix must have good adhesion between asphalt binder and aggregates in both dry and wet conditions. The adhesion loss in the aggregate-binder interface is one of the primarily responsible mechanisms for high moisture susceptibility in the mixes. It could be divided into two components, namely, active adhesion and passive adhesion. Active adhesion is the ability of binder to completely coat aggregates in mixing operation of asphalt mixes $[48,49]$. Active adhesion can also be represented by the term mixability. On the other hand, passive adhesion is the ability of the asphalt binder to remain coated on the surface of aggregate while being subjected to the external moisture and traffic (also represented as moisture susceptibility) [48, 49].

The effect of various fillers on the active adhesion was analyzed by measuring the time required by the aggregates in 
the mix to get uniformly coated with the binder. The total time elapsed between the moment of the addition of binder to the moment of all aggregates in the mix getting $100 \%$ coated is measured. In this study, the analysis of passive adhesion/moisture susceptibility of loose mixes and the compacted specimen was conducted using two empirical tests as per ASTM D 3625-12 [50] and AASHTO T283 guidelines, respectively. The loose asphalt mixes were submerged in the boiling water for 10 minutes (maintained at a temperature between 85 and $100^{\circ} \mathrm{C}$ ), and the retained asphalt binder coating on aggregates was calculated by visual observation. The three specimens were prepared at each OAC, and sets of 48 specimens ( 4 types of fillers $\times 4$ filler contents $\times 1$ OAC $\times 3$ replicates) were prepared for the calculation of active adhesion and passive adhesion of loose mixes, while the moisture resistance of compacted mixes was estimated by comparing their tensile strength ratio (TSR) [51]. In this analysis, two sets of Marshall specimens (conditioned and unconditioned) were prepared at 7\% air voids for each mix. The six specimens were prepared at each OAC, and a set of 96 specimens (4 types of fillers $\times 4$ filler contents $\times 1$ OAC $\times 2$ conditions of specimens $\times 3$ replicates) were prepared for the calculation of TSR. The conditioned specimens were then subjected to a cycle of freeze-thaw conditioning. The TSR of the mixes was then determined as the ratio of mean ITS of conditioned specimens to the mean ITS of unconditioned specimens. The mix having higher TSR value exhibited lower moisture susceptibility.

3.3.5. Ravelling Resistance. The ravelling resistance of asphalt mixes was estimated with the Cantabro loss test as per Spanish norm NLT-352/86 [52]. In this test, Marshall specimens were placed in the Los Angeles abrasion (without steel charges) and were subjected to 300 rotations at the rate of $33 \mathrm{rpm}$. Three specimens were prepared for each type of mix, and a total of 48 specimens (4 types of fillers $\times 4$ filler contents $\times 1$ OAC $\times 3$ replicates) were prepared for the calculation of ravelling resistance, and average values are reported. The percentage loss of weight suffered by the specimens was measured and termed as Cantabro loss. The mix which suffered lesser Cantabro loss exhibited better resistance against ravelling and vice versa.

3.3.6. Resilient Modulus. Resilient modulus $\left(M_{r}\right)$ is an integral parameter used in pavement design using mechanistic-empirical pavement design guidelines which analyze the ability of pavement layer to disperse load. $M_{r}$ of Marshall specimens was determined according to ASTM D4123-82 [53] at $35^{\circ} \mathrm{C}$ using a universal testing machine. The stress level used in testing should lie between 10 and $50 \%$ of the ITS, and hence the load corresponding to $10 \%$ of ITS was used for testing [53]. The haversine load pulse was used in analysis at $1 \mathrm{~Hz}$ frequency $(0.1 \mathrm{~s}$ load and $0.9 \mathrm{~s}$ rest period), while Poisson's ratio of each mix was taken as $0.35[15,54]$. Three specimens were prepared for each type of mix, and a total of 48 specimens ( 4 types of fillers $\times 4$ filler contents $\times 1$
$\mathrm{OAC} \times 3$ replicates) were prepared for the calculation of resilient modulus, and average values are reported. The resilient modulus was determined using the following equation:

$$
M_{r}=\frac{P(\nu+0.27)}{t \Delta \delta}
$$

where $M_{r}=$ resilient modulus (MPa), $P=$ repeated load $(N)$, $v=$ Poisson ratio, $t=$ specimen thickness $(\mathrm{mm})$, and $\delta=$ recoverable horizontal deformation $(\mathrm{mm})$.

\subsection{Design and Analysis of Flexible Pavements}

3.4.1. Design of Flexible Pavements. This objective of this section is to design most economical flexible pavement section utilizing various asphalt concrete mixes as surface course to support similar design traffic. The analysis was done according to IRC 37: 2018 specification which considers pavement as a multilayer system and uses "linear elastic layered theory" for its analysis [37]. In all sections, the pavement system was assumed to have asphalt surfacing, asphalt binder course, granulous base, and subbase course and subgrade. The primary material properties (stiffness moduli and Poisson's ratio) and layer thickness for each course are shown in Figure 2. Resilient modulus values of mixes determined in the previous section were adopted as elastic modulus values for the surface course. The design traffic volume is selected as the total traffic volume which pavement encounters during its service life. In this study, the design traffic volume is assumed to be 200 million standard axles (msa), which corresponds to a standard busy highway section having a very heavy traffic volume.

As per IRC 37: 2018, the layer thickness of the surface course should be selected in such a manner that the stress and strain obtained at the critical locations should not exceed the allowable strains. The allowable stress or strain is termed as the maximum stress or strain occurring at critical locations of the pavement system which leads to its failure. In this particular case, the tensile strain at the bottom fibre of the bottommost asphalt layer (binder course) and compressive strain at the top of the subgrade are considered as critical locations.

The allowable strains at these locations can be determined using subgrade rutting and asphalt fatigue equations (3) and (4) at a 90\% reliability factor with respective air void volume and bitumen volume in the mixtures [37].

Allowable vertical compressive strain at the top of the subgrade was calculated from the following equation:

$$
N_{r}=1.41 \times 10^{-8}\left[\frac{1}{\varepsilon_{v}}\right]^{4.5337},
$$

where $N_{f}$ is design traffic volume and $\varepsilon_{v}$ is the vertical compressive strain at the top of the subgrade.

Allowable tensile strain at the bottom fibre of the binder course was calculated from the following equation: 


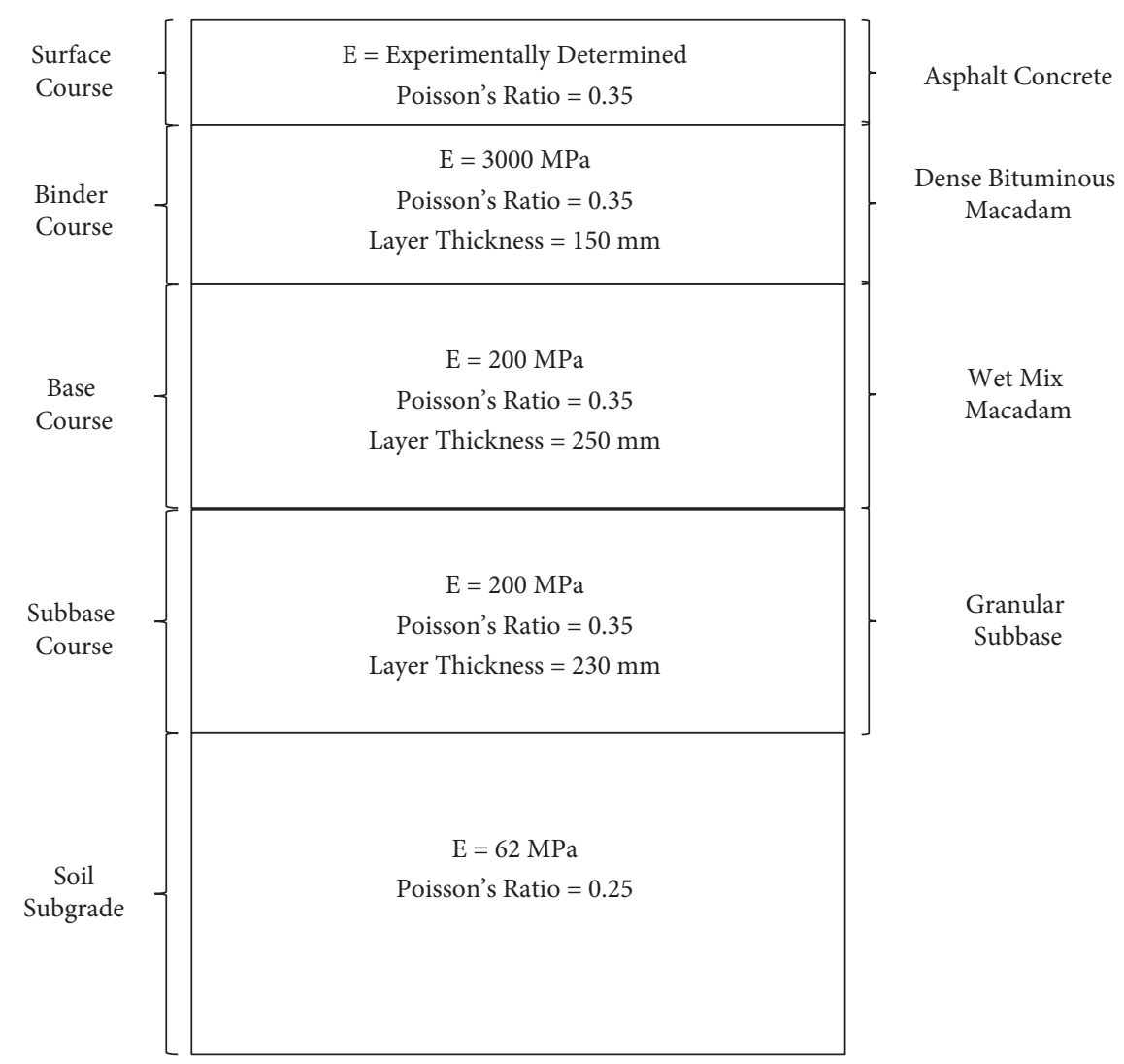

Figure 2: Pavement structure designed in this study.

$$
N_{f}=0.5161 \times C \times 10^{-4} \times\left[\frac{1}{\varepsilon_{t}}\right]^{3.89} \times\left[\frac{1}{M_{R}}\right]^{0.854},
$$

where $N_{f}$ is design traffic volume, $\varepsilon_{t}$ is the horizontal tensile strain at the bottom fibre of the binder course, and $M_{R}$ is the resilient modulus $(\mathrm{MPa})$ of the binder layer.

The factor " $C$ " is termed as the adjustment factor which is used to take account for the effect of variation in the volumetric parameters (air voids and effective binder volume) on the fatigue life of the bottommost asphalt course.

$$
\begin{aligned}
C & =10^{M}, \\
M & =4.84\left(\frac{V_{b e}}{V_{b e}+V_{a}}-0.69\right),
\end{aligned}
$$

where $V_{b e}$ and $V_{a}$ represent effective binder volume and volume of air voids in the binder course of the pavement. In this study, binder course is assumed to have $V_{b e}$ and $V_{a}$ equal to $3 \%$ and $11.5 \%$, respectively. These are commonly preferred at the pavement site to ensure satisfactory pavement performance [37]. Hence, the value of $C$ corresponding to these volumetric properties was calculated and taken as 3.155.

For each pavement system, the thickness of the surface course was assumed by trial and error (keeping other layer thicknesses constant) to ensure that the strains that occurred at critical locations should not exceed the allowable strains. The strains at different locations of the pavement system were determined using IITPAVE software which is prescribed by IRC: 37 guideline. The design thickness for the surface course was finalized as the minimum layer thickness (most economical) at which strains at critical locations should not exceed the allowable strains.

3.4.2. Cost Analysis of Designed Pavement Surface Course. The cost of materials needed to construct a single km of twolane $(7.00 \mathrm{~m})$ pavement surface course for design traffic volume is calculated in this section. The expenditures related to workmanship and machinery are not taken in the analysis, but only the material costs are taken into consideration. The surface layer thickness was determined in previous section, and the quantity of ingredients was calculated accordingly. The detailed steps involved in the assessment of the material quantity and their cost can be referred from the recently published study of the authors [30]. The price of pavement materials was taken according to the specification of Central Public Works Department, India [55]. GP was obtained directly from its dumping grounds, and hence its cost is taken as zero. The cost required in transferring SD from the stone crusher to pavement location was assumed to be same of that of transporting GP from its dumping ground to pavement site. The GP needed minimal processing since it was found to be already fine in their natural state. The GP processing (labour) cost was implied as $0.5 \%$ of the total material cost [30]. The cost incurred in transporting waste materials was assumed to be the same as that incurred in 
transferring conventional SD from its quarries to the pavement site.

3.4.3. Analysis of Global Warming Potential (GWP) of Designed Surface Courses. According to Intergovernmental Panel on Climate Change (IPCC), the GWP comprised of all substances which contribute to the climate change [56]. To analyze the GWP, the lifetime of a substance and its efficiency to act as a GHG are estimated. The life cycle of any pavement comprised of four different phases: material production, construction, use, and maintenance [57]. In this study, the GWP for various asphalt mixes was determined by comparing the GHG emission happened during the material production that is required to manufacture $1 \mathrm{~km}$ of flexible pavement section utilizing all twelve types of asphalt mixes as surface course.

The GWP for various asphalt mixes was assessed by comparing the green house gas (GHG) emission occurred in manufacturing $1 \mathrm{~km}$ of flexible pavement section utilizing all twelve types of asphalt mixes as a surface course. After the calculation of optimum design thickness for the surface courses for each type of mixes, the amount of material needed to construct $1 \mathrm{~km}$ of two-lane $(7 \mathrm{~m})$ surface course was calculated. The standard amount of emission (in terms of $\mathrm{kg}$ of $\mathrm{CO}_{2}$ equivalent) by different materials (coarse and fine aggregates, stone dust (SD), hydrated lime (HL), and asphalt binder) was taken from the several previously published peer reviewed studies [58-61]. European Union's Waste Framework Directive (2008/98/EC) defines "waste" as any substance or object which the holder discards or intends or is required to discard [62]. Since GP is discarded by its agency, it can be considered as waste. It was also stated beforehand that these materials were incorporated in the asphalt mixes directly without any physical or chemical modification. Hence, considering all these factors, the GWP of GP was assumed as zero. For the sake of simplification, construction, use, and maintenance phases were not taken into analysis. This is justified by the assumption that different production setups for every construction material do not influence the use and maintenance of the pavement.

\section{Discussion of Results}

4.1. Filler Characterization. The characteristics of fillers are stated in Table 3 and Figures 3(a) and 3(b). SD has the highest specific gravity while HL and GP had almost similar specific gravities. Thus, SD occupies lower volume in asphalt mix per unit weight. Particle size distribution curves are shown in Figure 3(a). HL was the finest filler while SD and GP were the coarsest fillers and have higher FM and $D_{50}$ values. SEM images of fillers are shown in Figure 3(b). GP and SD have relatively large, angular particles with smooth texture, while HL had smaller particles with rough texture. GP and HL fillers displayed relatively higher porosity as compared to SD as seen from their lower German filler values. The high porosity of filler may increase the OAC and rutting resistance of asphalt mixes [16]. Active clay in fillers can swell in presence of water and lower the adhesion between filler and asphalt, which weakens the asphalt mix. However, all fillers had low active clay content as indicated by their lower methylene blue value. HL and SD were found to have a predominance of Portlandite and dolomite in their composition. Both of them comprised of calcium-based minerals which reduce moisture sensitivity of asphalt mixes. GP consists of a high amount of silica as quartz which is usually linked with greater moisture sensitivity of asphalt mix [63]. However, all fillers displayed hydrophobic nature and exhibited superior affinity towards asphalt binder. Based on detailed preliminary characterization, all materials fulfilled the requirements of fillers in asphalt mixes.

\subsection{Performance of Asphalt Concrete Mixes}

4.2.1. Marshall Properties. The Marshall and volumetric properties of most of the mixes fulfilled the requirements specified in Indian specification (Table 4) [4]. However, mixes prepared with $8.5 \%$ of GL had marginally lower (13.9\%) VMA value than required.

Up to 7\% filler content, Marshall stability (MS) of mixes tends to improve with filler content because of toughening of asphalt mastic because of simultaneous growth in quantity of filler as well as lowering in OAC. However, there is a marginal drop in MS in GP and GL mixes containing $8.5 \%$ filler which might be attributed to the adhesion loss in mastic due to lower OAC and higher silica content of fillers. In general, it is observed that GL mixes had higher MS followed by SD and GP mixes due to the strengthening of asphalt mastic due to the greater fineness of HL. However, at $8.5 \%$ filler, mixes with SD had the highest stabilities followed by GL and GP mixes that may be because of the reduction in adhesion in GP and GL mixes caused by high silica content in the glass [64]. OAC reduced with the increase in filler amount due to asphalt "extender" behavior of fillers, which enable them to form same amount of mastic with higher filler content and lower binder content. Hence, mixes prepared with higher filler contents require lower binder content to the specified air voids $[11,16,64]$. Asphalt mixes containing GP exhibited lowest OAC followed by GP and SD mixes. HL is the finest filler followed by GP and SD. Hence, GL showed better asphalt extender effect than other fillers. Additionally, HL and GP have lower specific gravities, and hence they occupy larger volume when incorporated in same weight proportion. It consequently leaves a lower volume for binder accumulation, thus resulting in lowering of OAC in their mixes $[18,65]$.

4.2.2. Rutting Resistance. The permanent deformation (creep) of asphalt mixes decreased with the increase in filler content (Table 5). The trend is consistent for all filler contents and agrees with results obtained in previous studies $[16,17,64]$. For all mixes, both VMA and AFT decreased with increase in filler content. Previous studies have suggested that the mixes having lower VMA and apparent film thickness (AFT) tend to display better rutting resistance $[44,66]$. In general, GL mixes displayed the maximum 
TABLE 3: Details of characterization properties of fillers.

\begin{tabular}{|c|c|c|c|c|}
\hline Filler property & $\begin{array}{l}\text { Glass powder } \\
\text { (GP) }\end{array}$ & Hydrated lime (HL) & Stone dust (SD) & Inferences \\
\hline Specific gravity & 2.370 & 2.363 & 2.698 & $\begin{array}{l}\text { GP and HL have lower specific gravity than } \\
\text { SD, and thus they occupy larger volume in } \\
\text { asphalt mix in comparison to SD. Hence } \\
\text { mixes containing GP and HL has lower } \\
\text { OAC than conventional asphalt mixes } \\
\text { containing SD. }\end{array}$ \\
\hline $\begin{array}{l}\text { Methylene blue value } \\
(\mathrm{g} / \mathrm{kg})\end{array}$ & 1.25 & 0.25 & 3.25 & $\begin{array}{l}\text { All fillers have low MBV (less than 10) } \\
\text { which indicated the presence of lower } \\
\text { harmful clay content per unit weight of } \\
\text { material. }\end{array}$ \\
\hline $\begin{array}{l}\text { German filler value } \\
\text { (g) }\end{array}$ & 75 & 35 & 85 & $\begin{array}{l}\text { HL and SD were found to have lowest and } \\
\text { highest porosity/fractional voids per unit } \\
\text { weight, respectively. }\end{array}$ \\
\hline Fineness modulus & 4.66 & 2.93 & 5.38 & SD and HL were found to be coarsest and \\
\hline $\mathrm{D}_{50}(\mu \mathrm{m})$ & 19 & 9 & 21 & finest fillers, respectively. \\
\hline $\begin{array}{l}\text { Particle shape and } \\
\text { texture (SEM) }\end{array}$ & $\begin{array}{c}\text { Angular } \\
\text { particles with } \\
\text { smooth texture } \\
\end{array}$ & $\begin{array}{c}\text { Subangular and } \\
\text { granulous particles } \\
\text { with a rough texture }\end{array}$ & $\begin{array}{l}\text { Angular particles with } \\
\text { smooth to rough texture }\end{array}$ & $\begin{array}{l}\text { Particles with rough texture may negatively } \\
\text { affect workability and can also cause higher } \\
\text { asphalt absorption. }\end{array}$ \\
\hline $\begin{array}{l}\text { Primary } \\
\text { mineralogical } \\
\text { composition (XRD) }\end{array}$ & Quartz $\left(\mathrm{SiO}_{2}\right)$ & $\begin{array}{c}\text { Portlandite } \\
\left(\mathrm{Ca}(\mathrm{OH})_{2}\right) \text {, calcite } \\
\left(\mathrm{CaCO}_{3}\right)\end{array}$ & $\begin{array}{l}\text { Dolomite }\left(\mathrm{CaMg}\left(\mathrm{CO}_{3}\right)_{2}\right) \\
\text { quartz }\left(\mathrm{SiO}_{2}\right) \text {, ertixite } \\
\qquad\left(\mathrm{Na}_{2} \mathrm{Si}_{4} \mathrm{O}_{9}\right)\end{array}$ & $\begin{array}{l}\text { Absence of any harmful expansive clay } \\
\text { minerals. SD and HL consist of dolomite } \\
\text { and Portlandite, respectively, which is a } \\
\text { calcium-based water-insoluble mineral } \\
\text { having good asphalt adhesion. Quartz is } \\
\text { associated with poor moisture sensitivity. }\end{array}$ \\
\hline $\begin{array}{l}\text { Hydrophilic } \\
\text { coefficient }\end{array}$ & 0.81 & 0.75 & 0.77 & $\begin{array}{l}\text { All materials displayed a higher affinity } \\
\text { towards asphalt in comparison to water. }\end{array}$ \\
\hline
\end{tabular}

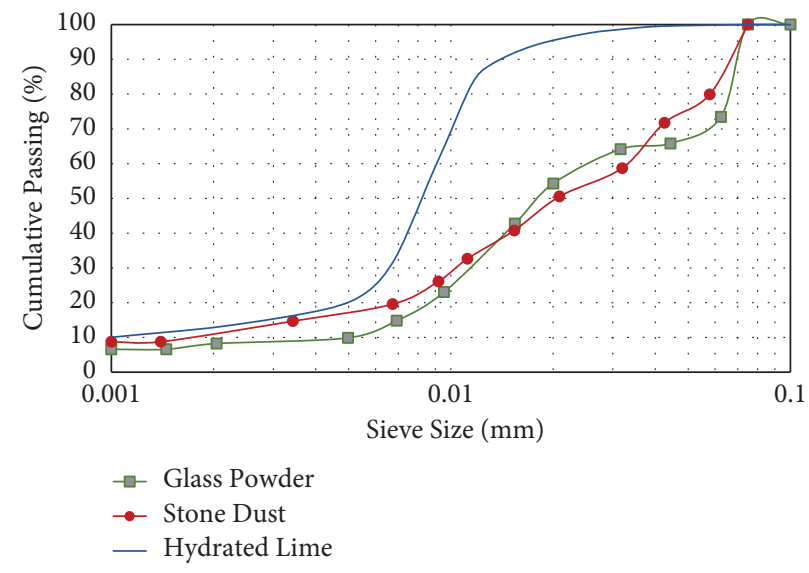

(a)
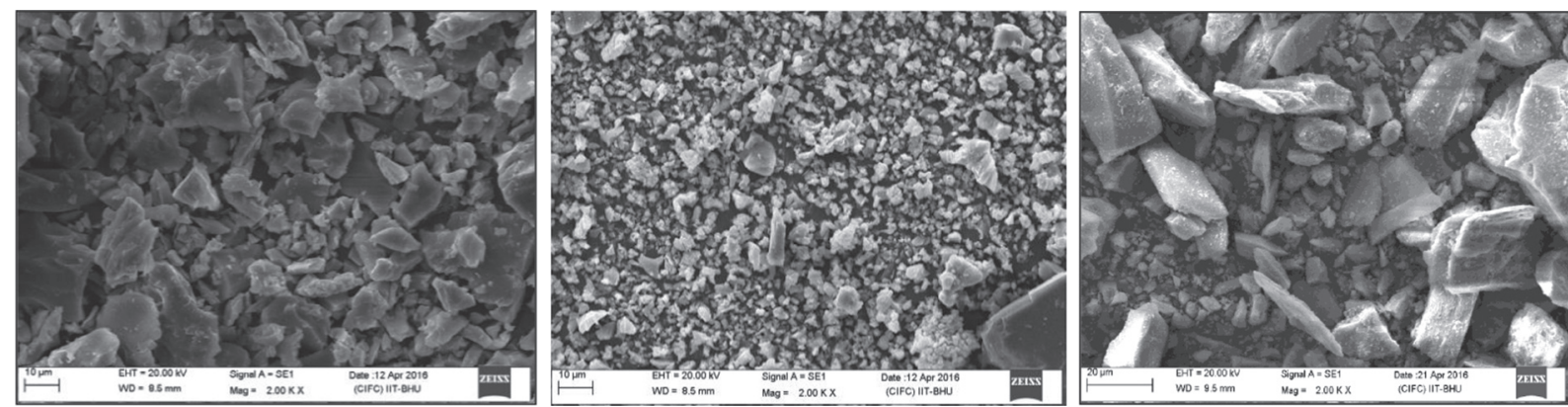

(b)

FIgURE 3: (a) Particle size distribution curves of various fillers. (b) SEM images of various fillers. 
TABLE 4: Marshall and volumetric properties of various mixes (standard deviations are mentioned in the parenthesis).

\begin{tabular}{|c|c|c|c|c|c|c|c|c|}
\hline Type of filler & $\begin{array}{c}\text { Filler content (\% of } \\
\text { the weight of } \\
\text { aggregates) }\end{array}$ & $\begin{array}{c}\text { OAC (\% of the } \\
\text { total weight of } \\
\text { mix) }\end{array}$ & $\begin{array}{c}\text { Bulk specific } \\
\text { gravity }\end{array}$ & VMA (\%) & VFA(\%) & $\begin{array}{c}\text { Marshall } \\
\text { stability (kN) }\end{array}$ & $\begin{array}{l}\text { Flow } \\
(\mathrm{mm})\end{array}$ & $\begin{array}{l}\text { AFT } \\
(\mu \mathrm{m})\end{array}$ \\
\hline \multirow{4}{*}{ Stone dust } & 4.0 & 6.20 & $2.430(0.005)$ & $17.02(0.18)$ & $74.22(0.94)$ & $12.22(0.30)$ & $3.43(0.18)$ & 7.85 \\
\hline & 5.5 & 5.95 & $2.444(0.006)$ & $16.21(0.18)$ & $74.43(1.01)$ & $13.99(0.47)$ & $3.62(0.18)$ & 7.34 \\
\hline & 7.0 & 5.38 & $2.453(0.010)$ & $15.31(0.31)$ & 74.79 (1.95) & $15.96(0.29)$ & $3.50(0.31)$ & 6.47 \\
\hline & 8.5 & 5.34 & $2.466(0.005)$ & $14.70(0.19)$ & $72.01(1.06)$ & $16.58(0.33)$ & $3.22(0.19)$ & 5.77 \\
\hline \multirow{4}{*}{ Glass powder } & 4.0 & 6.03 & $2.427(0.005)$ & $16.51(0.17)$ & $74.85(0.93)$ & $12.98(0.46)$ & $3.38(0.17)$ & 7.38 \\
\hline & 5.5 & 5.81 & $2.431(0.009)$ & $15.96(0.29)$ & $73.92(1.64)$ & $13.46(0.52)$ & $3.18(0.29)$ & 6.83 \\
\hline & 7.0 & 5.48 & $2.441(0.011)$ & $14.85(0.38)$ & $72.97(2.06)$ & $14.93(0.88)$ & $3.37(0.38)$ & 6.17 \\
\hline & 8.5 & 5.26 & $2.448(0.008)$ & $14.23(0.28)$ & 72.27 (1.67) & $14.52(0.62)$ & $2.95(0.28)$ & 5.62 \\
\hline \multirow{4}{*}{$\begin{array}{l}\text { Glass-hydrated } \\
\text { lime }\end{array}$} & 4.0 & 5.65 & $2.448(0.006)$ & $15.43(0.19)$ & $74.18(1.11)$ & $14.32(0.27)$ & $3.21(0.19)$ & 6.99 \\
\hline & 5.5 & 5.38 & $2.457(0.010)$ & $14.62(0.36)$ & $70.79(2.05)$ & $15.04(0.30)$ & $3.06(0.36)$ & 6.07 \\
\hline & 7.0 & 5.12 & $2.455(0.006)$ & $14.22(0.21)$ & $69.15(1.17)$ & $16.78(0.75)$ & $3.30(0.21)$ & 5.50 \\
\hline & 8.5 & 5.05 & $2.452(0.010)$ & $13.92(0.37)$ & $69.33(2.15)$ & $16.10(0.40)$ & $2.88(0.37)$ & 5.25 \\
\hline $\begin{array}{l}\text { Requirements [4] } \\
(\mathrm{min})\end{array}$ & $4-10$ & - & - & $14.00(\mathrm{~min})$ & $65-75$ & 9.00 & $2-4$ & \\
\hline
\end{tabular}

TABLE 5: Various properties of asphalt mixes at different filler contents (standard deviations are mentioned in the parenthesis).

\begin{tabular}{|c|c|c|c|c|c|c|c|c|c|}
\hline \multirow[b]{2}{*}{$\begin{array}{l}\text { Type of } \\
\text { filler }\end{array}$} & \multirow[b]{2}{*}{$\begin{array}{c}\text { Filler } \\
\text { content } \\
(\%)\end{array}$} & \multicolumn{8}{|c|}{ Properties of asphalt mix } \\
\hline & & $\begin{array}{l}\text { Permanent } \\
\text { deformation } \\
(\mathrm{mm})\end{array}$ & $\begin{array}{l}\text { Indirect } \\
\text { tensile } \\
\text { strength } \\
(\mathrm{kPa})\end{array}$ & $\begin{array}{l}\text { Fatigue life } \\
\text { (cycles) }\end{array}$ & $\begin{array}{l}\text { Mixing } \\
\text { time (s) }\end{array}$ & $\begin{array}{c}\text { Retained } \\
\text { asphalt } \\
\text { coverage (\%) }\end{array}$ & $\begin{array}{c}\text { Tensile } \\
\text { strength } \\
\text { ratio (\%) }\end{array}$ & $\begin{array}{c}\text { Cantabro } \\
\text { loss }(\%)\end{array}$ & $\begin{array}{c}\text { Resilient } \\
\text { modulus } \\
(\mathrm{MPa})\end{array}$ \\
\hline \multirow{4}{*}{ Stone dust } & 4.0 & $0.095(0.01)$ & $2614(132)$ & $2491(164)$ & $84(2.65)$ & $100(0.00)$ & $94.23(1.23)$ & $4.74(0.84)$ & $1360(117)$ \\
\hline & 5.5 & $0.085(0.01)$ & $2774(184)$ & $4201(221)$ & $89(4.04)$ & $100(0.00)$ & $93.28(1.02)$ & $3.86(0.65)$ & $1991(97)$ \\
\hline & 7.0 & $0.072(0.02)$ & $3124(226)$ & $6036(272)$ & $93(4.14)$ & $97(2.89)$ & $89.26(1.96)$ & $3.42(0.23)$ & $2630(101)$ \\
\hline & 8.5 & $0.06(0.01)$ & 3312 (118) & $6964(187)$ & $108(6.11)$ & $93(2.89)$ & $85.59(3.01)$ & $5.32(0.77)$ & $2930(88)$ \\
\hline \multirow{4}{*}{$\begin{array}{l}\text { Glass } \\
\text { powder }\end{array}$} & 4.0 & $0.075(0.01)$ & $2964(148)$ & $4324(267)$ & $107(5.57)$ & $75(5.00)$ & $54.05(4.85)$ & $3.94(0.61)$ & $1610(136)$ \\
\hline & 5.5 & $0.067(0.01)$ & 3108 (166) & $5932(174)$ & $133(9.17)$ & $68(2.89)$ & $39.47(5.59)$ & $3.56(0.47)$ & 2134 (157) \\
\hline & 7.0 & $0.045(0.01)$ & $3452(202)$ & $6432(265)$ & $153(3.46)$ & $55(5.00)$ & $17.65(6.38)$ & $5.16(0.88)$ & $2834(103)$ \\
\hline & 8.5 & $0.032(0.01)$ & $3654(154)$ & $5321(301)$ & $192(3.51)$ & $42(2.89)$ & $9.18(2.46)$ & $5.84(0.28)$ & $3072(102)$ \\
\hline \multirow{4}{*}{$\begin{array}{l}\text { Glass- } \\
\text { hydrated } \\
\text { lime }\end{array}$} & 4.0 & $0.06(0.02)$ & 3024 (157) & $4971(144)$ & $90(2.00)$ & $95(0.00)$ & $88.58(1.21)$ & $4.22(1.01)$ & $2042(106)$ \\
\hline & 5.5 & $0.04(0.01)$ & 3392 (209) & $6326(212)$ & $120(4.51)$ & $85(0.00)$ & $85.34(1.32)$ & $4.00(0.52)$ & $2542(96)$ \\
\hline & 7.0 & $0.025(0.00)$ & 3712 (119) & $7422(314)$ & $142(6.51)$ & $82(2.89)$ & $81.12(2.54)$ & $5.75(0.84)$ & $3111(131)$ \\
\hline & 8.5 & $0.015(0.00)$ & $3796(102)$ & $6886(137)$ & $183(4.73)$ & $68(2.89)$ & $71.27(3.99)$ & $5.95(0.36)$ & 3512 (114) \\
\hline
\end{tabular}

rutting resistance followed by GP and SD mixes. GL mixes displayed the lowest permanent deformation trailed by mixes containing GP and SD because of their lowest VMA and AFT. Both waste and composite filler mixes displayed lower permanent deformation and higher rutting resistance than conventional SD mixes. High resistance of GL mixes against permanent deformation may also be due to finest particle size of HL, which tends to uniformly distribute in the mix and increase their stiffness.

4.2.3. Cracking Resistance. The ITS values of the mixes at $0^{\circ} \mathrm{C}$ were increased with filler content irrespective of the filler type (Table 5). The increase in ITS with filler content is due to increase in mastic strength due to the growth in filler proportion and decline in binder proportion. An increase in filler content in mixes also increased the density of mixes, which might also be a possible reason for the increase in ITS values [67]. The mixes having waste fillers showed superior ITS than SD mixes. GL mixes showed the highest ITS followed by GP and SD mixes. The increase in the volume fraction of filler tends to increase the stiffness of the mastic and mixes, thus improving the ITS. Since GL and GP occupied the highest volume due to their low specific gravity, they exhibited higher ITS values. High ITS values of GL and GP mixes might be attributed to their fineness due to which they distribute uniformly and form an integrated structure which resulted in superior ITS $[54,68]$.

Fatigue lives of GL and GP mixes improved with filler quantity up to $7 \%$. However, in case of SD mixes, fatigue life increased up to $8.5 \%$ filler content (Table 5 ). The primary reason for this phenomenon is the tendency of filler to display "crack pinning" behavior in the filler binder mastic which slows down the growth of microcracks by acting as barriers and deflects the crack propagation [69-71]. Another reason for the improvement in fatigue life with filler content may be due to the mode of testing. It was observed that fatigue life of mixes improved with growth in stiffness, when controlled stress mode of testing is adopted [72, 73]. In general, GL mixes displayed highest fatigue lives followed by 
GP and SD mixes. HL and GP have lower specific gravity than SD, while their mixes have lower OAC than SD mixes. Hence, fillers in higher volume behave as barrier in relatively less quantity of binder, which deflected more number of cracks and improved the fatigue lives of their mixes. The asphalt mix's fatigue life is also dependent on the filler bitumen bonding. In the case of mixes having $8.5 \%$ filler, the SD filler maintained its bonding with bitumen (due to dolomite in composition), while the bond GP and GL fillers got weakened (high silica concentration) which led to a decrease in the fatigue life of their mixes.

4.2.4. Asphalt Aggregate Adhesion and Moisture Susceptibility. SD mixes displayed superior active and passive adhesion followed by GL and GP mixes, respectively (Table 5). They had the least mixing time and highest bitumen coverage than GL and GP mix, respectively (Table 5). The dolomite in SD and higher OAC of their mixes may be responsible factors for their better adhesion. GP mix showed adhesions due to presence of high amount of silica $[29,31]$. Fillers containing high amount of silica form weak mechanical (van der Waals force) bond with asphalt binder which resulted in poor adhesion [74, 75]. GL mixes have displayed almost similar performance as SD mixes at $4 \%$ content, which may be due to the adhesion promoter behavior of HL. However, this influence seemed to diminish at higher filler contents (7\% and $8.5 \%$ ) and GL mixes delivered performance almost similar to GP mixes.

The passive adhesion in the compacted specimen is shown in Table 5. TSR values of mixes reduced with the higher filler quantity which was caused due to lowering in OAC and AFT of mixes. All asphalt mixes should have atleast $80 \%$ TSR as per Indian specifications [4]. GP mixes displayed poor performance against moisture, and none of the GP modified mixes satisfied the given criteria (Table 5). However, it was found that replacement of $2 \%$ glass powder with hydrated lime (HL) had dramatically improved the values of TSR. The improvement in performance is due to anti-stripping nature of $\mathrm{HL}$ which contains Portlandite $\left(\mathrm{Ca}(\mathrm{OH})_{2}\right)$ in it $[12,33]$. The hydrated lime was found to improve the moisture resistance of asphalt mixes by interacting with carboxylic acid in binder and forming water-insoluble calcium salts [76]. The improvement in moisture resistance in GL mixes might also be due to the formation of cementitious compounds because of the reaction of pozzolanic compound $\mathrm{SiO}_{2}$ and lime in the presence of water [77]. GL mixes displayed significantly high TSR values than GP mixes and have shown satisfactory TSR up to $7 \%$ of filler content in the mix. Hence, it can be said that up to $5 \%$ of GP along with $2 \%$ of HL can be satisfactorily utilized as a filler.

4.2.5. Ravelling Resistance. Ravelling resistance of all mixes was assessed by comparing their Cantabro loss (Table 5). It seemed that Cantabro losses reduced with filler content up to a limit followed by a marginal decline. The reduction in Cantabro loss might be attributed to mastic hardening with the increase in filler proportion, which improved the impact resistance of the mixes [78]. However, excessive stiffening and lowering of $\mathrm{OAC}$ at higher filler contents reduced the adhesion which consequently increased the losses. GP and GL mixes showed lower Cantabro losses (at 4 and 5.5\%) than SD mixes, while SD mixes displayed better performance at higher filler contents (7 and 8.5\%).

4.2.6. Resilient Modulus. The resilient modulus $\left(\mathrm{M}_{\mathrm{r}}\right)$ of mixes is stated in Table 5 and was found to increase with the filler content. It is due to the lower OBC of waste filler modified mixes and due to fineness of filler particles $[54,75]$. In general, GL mixes showed highest $M_{r}$ values followed by GP and SD mixes. Hence, flexible pavements with GP and GL mixes may support same volume of traffic with relatively lower layer thickness than SD mix.

\subsection{Analysis of Flexible Pavements}

4.3.1. Structural Design of Flexible Pavements. The allowable vertical compressive and horizontal tensile strains at critical locations were found to be $0.273 \times 10^{-4}$ and $0.134 \times 10^{-3}$, respectively, as per equations (4) and (5). The minimum surface layer thickness which ensures that the strain in critical location remains lower than allowable strains was determined using IITPAVE software [37]. The thicknesses corresponding to each mix are stated in Table 6. It is seen that the growth in filler content significantly improved the stiffness of mixes, which ultimately resulted in a considerable reduction in required surface layer thickness. The comparison of layer thickness of various mixes with SD mix containing 4\% filler (SD 4) is also reported in Table 6. GL mixes displayed the lowest layer thickness followed by GP and SD mixes. The use of waste fillers seemed to significantly reduce the required thickness which resulted in a momentous saving in material and workmanship.

4.3.2. Cost Analysis of Flexible Pavements. The amount of ingredients consumed to construct $1 \mathrm{~km}$ of 2-lane surface course is stated in Table 7 along with their respective cost. The cost comparison of various surface courses with SD mix containing 4\% filler (SD 4) mix is made in Table 8 . It can be clearly seen that cost of surface courses significantly declined with increase in filler content. Since binder has the highest cost, the reduction in cost of different mixes was attributed to the its relative savings. Asphalt mixes containing GL mixes were found to be most economical followed by GP and $\mathrm{SD}$ mixes. The use of GL and GP resulted in momentous savings of 33 and 35\%, respectively. In the case of SD mixes, the growth in filler content from 4 to $8.5 \%$ has resulted in a cost reduction of up to $30 \%$.

4.3.3. Analysis of GWP of Flexible Pavements. The GWP of various surface courses was analyzed by comparing their GHG, which is shown in Tables 9 and 10. Similar to the cost analysis, the growth in filler content tends to significantly reduce the GWP of surface courses. The GP mixes can be 
TABLE 6: The adopted thickness and computed strains (using IITPAVE).

\begin{tabular}{|c|c|c|c|c|c|c|}
\hline $\begin{array}{l}\text { Type of } \\
\text { filler }\end{array}$ & $\begin{array}{l}\text { Percentage of } \\
\text { filler in the mix } \\
\qquad(\%)\end{array}$ & $\begin{array}{c}\text { Resilient } \\
\text { modulus at } \\
35^{\circ} \mathrm{C}(\mathrm{MPa})\end{array}$ & $\begin{array}{l}\text { The adopted } \\
\text { thickness of } \\
\text { surface course } \\
(\mathrm{mm})\end{array}$ & $\begin{array}{l}\text { Computed vertical } \\
\text { compressive strain } \\
\text { at top of the } \\
\text { subgrade }\end{array}$ & $\begin{array}{l}\text { Computed horizontal } \\
\text { tensile strain at the } \\
\text { bottom of the } \\
\text { bottommost bituminous } \\
\text { layer }\end{array}$ & $\begin{array}{l}\text { Comparison of the } \\
\text { surface layer thickness of } \\
\text { different mixes with } \\
\text { respect to SD } 4 \text { mix (\%) }\end{array}$ \\
\hline \multirow{4}{*}{ Stone dust } & 4 & 1360 & 70 & $0.2374 \times 10^{-3}$ & $0.1335 \times 10^{-3}$ & 100 \\
\hline & 5.5 & 1991 & 62 & $0.2330 \times 10^{-3}$ & $0.1339 \times 10^{-3}$ & 88.57 \\
\hline & 7 & 2630 & 57 & $0.2294 \times 10^{-3}$ & $0.1339 \times 10^{-3}$ & 81.43 \\
\hline & 8.5 & 2930 & 56 & $0.2271 \times 10^{-3}$ & $0.1334 \times 10^{-3}$ & 80.00 \\
\hline \multirow{4}{*}{$\begin{array}{l}\text { Glass } \\
\text { powder }\end{array}$} & 4 & 1610 & 66 & $0.2358 \times 10^{-3}$ & $0.1339 \times 10^{-3}$ & 94.29 \\
\hline & 5.5 & 2134 & 61 & $0.2319 \times 10^{-3}$ & $0.1337 \times 10^{-3}$ & 87.14 \\
\hline & 7 & 2834 & 56 & $0.2281 \times 10^{-3}$ & $0.1338 \times 10^{-3}$ & 80.00 \\
\hline & 8.5 & 3072 & 54 & $0.2267 \times 10^{-3}$ & $0.1336 \times 10^{-3}$ & 77.14 \\
\hline \multirow{4}{*}{$\begin{array}{l}\text { Glass- } \\
\text { hydrated } \\
\text { lime }\end{array}$} & 4 & 2042 & 62 & $0.2323 \times 10^{-3}$ & $0.1335 \times 10^{-3}$ & 88.57 \\
\hline & 5.5 & 2542 & 58 & $0.2294 \times 10^{-3}$ & $0.1336 \times 10^{-3}$ & 82.86 \\
\hline & 7 & 3111 & 55 & $0.2263 \times 10^{-3}$ & $0.1334 \times 10^{-3}$ & 78.57 \\
\hline & 8.5 & 3512 & 53 & $0.2247 \times 10^{-3}$ & $0.1331 \times 10^{-3}$ & 75.71 \\
\hline
\end{tabular}

TABLE 7: Cost analysis of various mixes.

\begin{tabular}{|c|c|c|c|c|c|c|c|c|c|c|}
\hline $\begin{array}{l}\text { Type of } \\
\text { filler }\end{array}$ & $\begin{array}{c}\text { Filler } \\
\text { content } \\
(\%)\end{array}$ & $\begin{array}{l}\text { Quantity } \\
\text { of } \\
\text { bitumen } \\
\text { (ton } / \mathrm{km} \text { ) }\end{array}$ & $\begin{array}{c}\text { Quantity of } \\
\text { coarse } \\
\text { aggregate } \\
\left(\mathrm{m}^{3} / \mathrm{km}\right)\end{array}$ & $\begin{array}{l}\text { Quantity of } \\
\text { fine } \\
\text { aggregate } \\
\left(\mathrm{m}^{3} / \mathrm{km}\right)\end{array}$ & $\begin{array}{c}\text { Quantity } \\
\text { of SD } \\
\left(\mathrm{m}^{3} / \mathrm{km}\right)\end{array}$ & $\begin{array}{c}\text { Quantity } \\
\text { of GP } \\
\left(\mathrm{m}^{3} / \mathrm{km}\right)\end{array}$ & $\begin{array}{l}\text { Quantity } \\
\text { of } \\
\text { hydrated } \\
\text { lime } \\
\text { (ton } / \mathrm{km} \text { ) }\end{array}$ & $\begin{array}{c}\text { Total } \\
\text { material } \\
\text { cost (INR/ }\end{array}$ & $\begin{array}{l}\text { Processing } \\
\text { cost }(0.5 \% \text { of } \\
\text { material cost })\end{array}$ & $\begin{array}{l}\text { Final cost } \\
(\mathrm{INR} / \mathrm{km})\end{array}$ \\
\hline $\begin{array}{l}\text { CPWD } \\
\text { rates }\end{array}$ & & $\begin{array}{c}\text { INR } \\
39570 / \text { ton }\end{array}$ & $\begin{array}{c}\text { INR } 1350 / \\
\mathrm{m}^{3} \\
\end{array}$ & $\begin{array}{c}\text { INR } 1350 / \\
\mathrm{m}^{3} \\
\end{array}$ & $\begin{array}{c}\text { INR } \\
1400 / \mathrm{m}^{3} \\
\end{array}$ & 0 & $\begin{array}{l}\text { INR } 2900 / \\
\text { ton }\end{array}$ & & & \\
\hline \multirow{4}{*}{ Stone dust } & 4.0 & 78.70 & 151.18 & 236.68 & 16.49 & 0 & 0 & $36,60,976$ & 0 & $36,60,976$ \\
\hline & 5.5 & 67.10 & 135.09 & 206.01 & 20.25 & 0 & 0 & $31,44,147$ & 0 & $31,44,147$ \\
\hline & 7.0 & 55.65 & 125.50 & 186.31 & 23.95 & 0 & 0 & $26,56,573$ & 0 & $26,56,573$ \\
\hline & 8.5 & 54.53 & 124.01 & 179.08 & 28.74 & 0 & 0 & $26,07,250$ & 0 & $26,07,250$ \\
\hline \multirow{4}{*}{$\begin{array}{l}\text { Glass } \\
\text { powder }\end{array}$} & 4.0 & 71.95 & 142.66 & 223.34 & 0 & 17.71 & 0 & $33,41,227$ & 16,706 & $33,57,933$ \\
\hline & 5.5 & 64.03 & 132.42 & 201.95 & 0 & 22.60 & 0 & $29,85,075$ & 14,925 & $30,00,000$ \\
\hline & 7.0 & 55.48 & 122.55 & 181.93 & 0 & 26.62 & 0 & $26,06,267$ & 13,031 & $26,19,298$ \\
\hline & 8.5 & 51.38 & 118.82 & 171.59 & 0 & 31.34 & 0 & $24,24,978$ & 12,125 & $24,37,103$ \\
\hline Glass- & 4.0 & 63.62 & 135.80 & 212.59 & 0 & 8.43 & 19.98 & $30,45,777$ & 15,229 & $30,61,006$ \\
\hline hydrated & 5.5 & 56.72 & 127.91 & 195.07 & 0 & 13.89 & 18.82 & $27,34,973$ & 13,675 & $27,48,648$ \\
\hline lime & 7.0 & 51.00 & 121.57 & 180.47 & 0 & 18.86 & 17.88 & $24,77,864$ & 12,389 & $24,90,254$ \\
\hline composite & 8.5 & 48.38 & 117.10 & 169.10 & 0 & 23.62 & 17.23 & $23,50,835$ & 11,754 & $23,62,589$ \\
\hline
\end{tabular}

Note. $1 \$ \approx 74.82$ INR (on 13/08/2020).

considered as most environmentally friendly, and use of GP at higher quantities (8.5\%) is expected to reduce the GHG emission by $35 \%$. This might be due to lower consumption of bitumen by these mixes. Interestingly, it can be observed that GL mixes displayed higher GHG emission amongst all mixes, despite having lower OAC and surface layer thickness. The higher GWP of these mixes might be attributed to the hydrated lime which generates good amount of $\mathrm{CO}_{2}$ during its production. It must also be noted that surface course containing GL filler at 7 and $8.5 \%$ exhibited almost similar GHG as SD 4 mixes. Hence, utilization of GL at higher filler contents could not only be environmentally friendly but also be significantly cheaper than conventional SD 4 mixes. The use of GP and GL as fillers also conserves momentous amount of non-removable resources (aggregates, stone dust, and asphalt binder) in each $\mathrm{km}$ of surface layer construction (Table 9). The single $\mathrm{km}$ of two-lane surface course made with GL and GP fillers is expected to conserve up to 324 and 312 tons of aggregates and stone dust in comparison to SD 4 mixes. The use of GL and GL surface course also saves up to 27 and 30 tons of asphalt binder in each $\mathrm{km}$ of road construction. It will also be helpful in reducing the cost of transportation, workmanship, and the time of road construction. Up to 74 tons of waste GP can be consumed in the construction of a single $\mathrm{km}$ of such pavement, while up to 56 tons of waste GP can be consumed in the form of GL composite. This will significantly resolve the issue regarding the safe disposal of GP. GL 7 mix can be considered as the most superior amongst all mixes. Not only this mix showed satisfactory resistance against moisture and superior stiffness and cracking resistance than SD 4 mix but also surface courses made with it were found to be $21 \%$ more 
TABLE 8: Comparison of the final cost of different mixes.

The total cost of mixes with respect to SD mix containing $4 \%$ filler (SD 4)

Filler type

Filler content

\begin{tabular}{lcccr} 
& $4 \%$ & $5.5 \%$ & $7 \%$ & $8.5 \%$ \\
\hline Stone dust & 100 & 85.88 & 72.56 & 71.22 \\
Glass powder & 91.27 & 81.95 & 71.55 & 66.57 \\
Glass lime & 86.31 & 75.08 & 68.02 & 64.53 \\
\hline
\end{tabular}

TABLE 9: Global warming potential of various mixes.

\begin{tabular}{|c|c|c|c|c|c|c|c|c|c|c|}
\hline $\begin{array}{l}\text { Type of } \\
\text { filler } \\
\text { GHG } \\
\text { emission } \\
\text { (kgCO }_{2} \\
\text { equivalent/ } \\
\text { kg) }\end{array}$ & $\begin{array}{c}\text { Filler } \\
\text { content } \\
(\%)\end{array}$ & $\begin{array}{l}\text { Quantity } \\
\text { of } \\
\text { bitumen } \\
\text { (ton } / \mathrm{km} \text { ) }\end{array}$ & $\begin{array}{l}\text { Quantity } \\
\text { of coarse } \\
\text { aggregate } \\
\text { (ton } / \mathrm{km} \text { ) }\end{array}$ & $\begin{array}{l}\text { Quantity } \\
\text { of fine } \\
\text { aggregate } \\
\text { (ton } / \mathrm{km} \text { ) }\end{array}$ & $\begin{array}{c}\text { Quantity } \\
\text { of SD } \\
\text { (ton } / \mathrm{km})\end{array}$ & $\begin{array}{c}\text { Quantity } \\
\text { of GP } \\
\text { (ton } / \mathrm{km})\end{array}$ & $\begin{array}{l}\text { Quantity } \\
\text { of } \\
\text { hydrated } \\
\text { lime } \\
\text { (ton } / \mathrm{km} \text { ) }\end{array}$ & $\begin{array}{c}\text { Total } \\
\text { emission } \\
\left(\text { kgCO }_{2}\right. \\
\text { equivalent })\end{array}$ & $\begin{array}{l}\text { Savings in } \\
\text { conventional } \\
\text { aggregates } \\
\text { with respect to } \\
\text { SD } 4 \text { mix (ton) }\end{array}$ & $\begin{array}{l}\text { Savings in } \\
\text { bitumen } \\
\text { with } \\
\text { respect to } \\
\text { SD } 4 \text { mix } \\
\text { (ton) }\end{array}$ \\
\hline \multirow{4}{*}{ Stone dust } & 4.0 & 78.70 & 422.56 & 644.96 & 44.48 & 0 & 0 & 36419 & 0 & 0 \\
\hline & 5.5 & 67.10 & 377.56 & 561.38 & 54.65 & 0 & 0 & 31170 & 138.75 & 11.70 \\
\hline & 7.0 & 55.65 & 350.78 & 507.70 & 64.62 & 0 & 0 & 26107 & 229.18 & 23.05 \\
\hline & 8.5 & 54.53 & 346.61 & 487.99 & 77.53 & 0 & 0 & 25602 & 265.97 & 24.17 \\
\hline \multirow{4}{*}{$\begin{array}{l}\text { Glass } \\
\text { powder }\end{array}$} & 4.0 & 71.95 & 398.74 & 608.61 & 0 & 41.97 & 0 & 33270 & 104.65 & 6.75 \\
\hline & 5.5 & 64.03 & 370.12 & 550.31 & 0 & 53.57 & 0 & 29670 & 191.57 & 14.67 \\
\hline & 7.0 & 55.48 & 342.53 & 495.77 & 0 & 63.10 & 0 & 25813 & 273.71 & 23.22 \\
\hline & 8.5 & 51.38 & 332.11 & 467.57 & 0 & 74.29 & 0 & 23695 & 312.32 & 27.32 \\
\hline \multirow{4}{*}{$\begin{array}{l}\text { Glass lime } \\
\text { composite }\end{array}$} & 4.0 & 63.62 & 379.55 & 579.31 & 0 & 19.98 & 19.98 & 45277 & 153.14 & 15.08 \\
\hline & 5.5 & 56.72 & 357.51 & 531.56 & 0 & 32.93 & 18.82 & 41245 & 222.93 & 21.98 \\
\hline & 7.0 & 51.00 & 339.78 & 491.79 & 0 & 44.71 & 17.88 & 37928 & 280.43 & 27.70 \\
\hline & 8.5 & 48.38 & 327.30 & 460.80 & 0 & 55.99 & 17.23 & 36183 & 323.90 & 30.32 \\
\hline
\end{tabular}

TABle 10: Comparison of GWP of different mixes.

GWP of mixes with respect to SD mix containing $4 \%$ filler (SD 4)

Filler type

\begin{tabular}{lcccc} 
& $4 \%$ & $5.5 \%$ & $7 \%$ & \\
\hline Stone dust & 100 & 85.59 & 71.69 & 70.30 \\
Glass powder & 91.35 & 81.47 & 70.88 & 65.06 \\
Glass lime & 124.32 & 113.25 & 104.14 & 99.35 \\
\hline
\end{tabular}

economical. The construction of single $\mathrm{km}$ of GL 7 surface course can also conserve up to 280 and 28 tons of aggregates and asphalt binder, respectively, as well as utilize 45 tons of GP.

The comparsion of obtained results is also made with the previous major literatures as stated in Table 11. It can be clearly observed that in comparison to the previous literatures, current study explored the performance of asphalt mixes containing variable amounts of GP and GL fillers in more multifaceted manner. Unlike previous studies, it addressed a critical issue concerning the moisture sensitivity of asphalt mixes containing GP in significant detail. Additionally, it also explored the vital aspects concerning the cost and environmental sustainability of GP incorporation, which has not been done before. This study not only conclusively proved that the incorporation of GP alone as filler can increase moisture sensitivity of asphalt mix but also suggested a manner to maximize the utilization of GP in the form of GL composite filler, while maintaining the engineering, economical, and environmental viability of prepared asphalt mixes. 
TABLE 11: Comparison of results of this study with the previous studies.

\begin{tabular}{|c|c|c|c|c|c|c|}
\hline \multirow{3}{*}{$\begin{array}{l}\text { Property of mix } \\
\text { Conventional filler }\end{array}$} & \multicolumn{6}{|c|}{$\begin{array}{l}\text { Comparison of performance of GP incorporated asphalt mixes with the conventional asphalt mixes having same filler } \\
\text { content }\end{array}$} \\
\hline & \multicolumn{4}{|c|}{ Previous literatures } & \multicolumn{2}{|c|}{ Current study } \\
\hline & $\begin{array}{l}\text { Saltan et al. [27] } \\
\text { Stone dust }\end{array}$ & $\begin{array}{l}\text { Arabani et al. [15] } \\
\text { Stone dust }\end{array}$ & $\begin{array}{l}\text { Simone et al. [28] } \\
\text { Stone dust }\end{array}$ & $\begin{array}{c}\text { Choudhary et al. [30] } \\
\text { Stone dust }\end{array}$ & GP Stone & dust ${ }^{G L}$ \\
\hline OAC & $10 \%(\uparrow)$ & $6 \%(\downarrow)$ & $0 \%$ & $2 \%(\uparrow)$ & $1-3 \%(\downarrow)$ & $5-9 \%(\downarrow)$ \\
\hline Marshall stability & $24 \%(\downarrow)$ & $21 \%(\uparrow)$ & - & $6 \%(\downarrow)$ & $12 \%(\downarrow)-6 \%(\uparrow)$ & $3 \%(\downarrow)-17 \%(\uparrow)$ \\
\hline Rutting resistance & - & $51 \%(\uparrow)$ & - & - & $0-100 \%(\downarrow)$ & $0-100 \%(\downarrow)$ \\
\hline Cracking resistance & - & $124 \%(\uparrow)$ & $12 \%(\downarrow)-15 \%(\uparrow)$ & $5 \%(\uparrow)$ & $\begin{array}{c}24 \%(\downarrow)-73 \% \\
(\uparrow)\end{array}$ & $1 \%(\downarrow)-100 \%(\uparrow)$ \\
\hline Moisture resistance & - & - & - & $80 \%(\downarrow)$ & $42-89 \%(\downarrow)$ & $6-16 \%(\downarrow)$ \\
\hline $\begin{array}{l}\text { Ravelling } \\
\text { resistance }\end{array}$ & - & - & - & - & $\begin{array}{c}17 \%(\uparrow)-10 \% \\
(\downarrow)\end{array}$ & $\begin{array}{c}11 \%(\uparrow)-21 \% \\
(\downarrow)\end{array}$ \\
\hline Resilient modulus & - & $118 \%(\uparrow)$ & $0-15 \%(\uparrow)$ & $8 \%(\uparrow)$ & $5-18 \%(\uparrow)$ & $20-50 \%(\uparrow)$ \\
\hline Cost & - & - & - & $2 \%(\uparrow)$ & $9 \%(\downarrow)-2 \%(\uparrow)$ & $6-9 \%(\downarrow)$ \\
\hline GHG emission & - & - & - & $2 \%(\downarrow)$ & $7-10 \%(\downarrow)$ & $24-40 \%(\uparrow)$ \\
\hline
\end{tabular}

Note. $(\uparrow)$ : increase in comparison to conventional mix; $(\downarrow)$ : decrease in comparison to conventional mix.

\section{Conclusions}

The conclusions obtained are as follows:

(i) GP, SD, and HL displayed traits of good fillers because of their fineness, low clay content, and hydrophobic nature. All asphalt concrete mixes prepared with GP and GL fillers (except GL mixes prepared at $8.5 \%$ filler content) showed superior Marshall and volumetric properties than conventional SD mixes.

(ii) OAC of all mixes decreased with growth in filler content due to filler's asphalt binder extender action. GL filler modified mixes displayed the lowest OAC in all cases and have the highest Marshall stabilities in most of the cases.

(iii) The resistance against cracking and rutting increased with the filler content. GL mixes exhibited better resistance due to the fine nature of GL and low VMA of the prepared mixes. GL and GP mixes also displayed satisfactory resistance against ravelling at lower filler contents.

(iv) GP displayed poor performance against moisture and in terms of adhesion. GP mixes failed to fulfill the minimum requirement of TSR at any filler content. GL mixes displayed satisfactory TSR values up to $7 \%$ filler content ( $5 \% \mathrm{GP}+2 \%$ lime). Hence, GP can be utilized up to $5 \%$ along with $2 \% \mathrm{HL}$ to form mixes with satisfactory moisture resistance.

(v) GL and GP mixes had higher resilient modulus and displayed better load distribution behavior than SD mixes. The pavement structure containing these mixes supported similar design traffic at a much lower thickness of pavements.

(vi) The pavement consisting of GL and GP mixes resulted in reduction of cost of the pavements up to 35 and $33 \%$ in comparison to conventional SD $4 \mathrm{mix}$. The construction of each $\mathrm{km}$ of surface course with these mixes can also conserve 324 and 312 tons of natural aggregates, respectively. GP mixes were found to be most environmentally friendly since they displayed 35\% lower GWP than SD 4 mixes

(vii) GL 7 mix was found to be the most superior amongst all mixes. It exhibited better laboratory performance, and the asphalt pavements made with it was also found to be $21 \%$ more economical. Use of this mix can also conserve 280 tons and 28 tons of conventional aggregates and binder, respectively.

In conclusion, it could be said that the utilization of GP in the form of waste and composite filler could be an efficient solution for the ecofriendly disposal of glass waste. The utilization of GP and GL fillers was proven to form asphalt mixes exhibiting superior engineering performance in a more economical and environmentally friendly manner.

\section{Data Availability}

All data and models generated or used during the study are included within the article.

\section{Conflicts of Interest}

The authors declare that there are no conflicts of interest.

\section{References}

[1] A. Gupta, P. Kumar, and R. Rastogi, "Mechanistic-empirical approach for design of low volume pavements," International Journal of Pavement Engineering, vol. 16, no. 9, pp. 797-808, 2015.

[2] J. Choudhary, B. Kumar, and A. Gupta, "Performance evaluation of bauxite residue modified asphalt concrete mixes," European Journal of Environmental and Civil Engineering, vol. 48, pp. 1-17, 2019.

[3] A. Kuity, S. Jayaprakasan, and A. Das, "Laboratory investigation on volume proportioning scheme of mineral fillers in 
asphalt mixture," Construction and Building Materials, vol. 68, pp. 637-643, 2014.

[4] MoRTH (Ministry of Road Transport and Highways), Specifications for Road and Bridge Works (Fifth Revision), Indian Road Congress, New Delhi, India, 2013.

[5] B. Barra, L. Momm, Y. Guerrero, and L. Bernucci, "Characterization of granite and limestone powders for use as fillers in bituminous mastics dosage," Anais da Academia Brasileira de Ciências, vol. 86, no. 2, pp. 995-1002, 2014.

[6] D. Lesueur, A. Teixeira, M. M. Lázaro, D. Andaluz, and A. Ruiz, "A simple test method in order to assess the effect of mineral fillers on bitumen ageing," Construction and Building Materials, vol. 117, pp. 182-189, 2016.

[7] C. Li, Z. Chen, S. Wu, B. Li, J. Xie, and Y. Xiao, "Effects of steel slag fillers on the rheological properties of asphalt mastic," Construction and Building Materials, vol. 145, pp. 383-391, 2017.

[8] A. K. Das and D. Singh, "Investigation of rutting, fracture and thermal cracking behavior of asphalt mastic containing basalt and hydrated lime fillers," Construction and Building Materials, vol. 141, pp. 442-452, 2017.

[9] Y. Chen, S. Xu, G. Tebaldi, and E. Romeo, "Role of mineral filler in asphalt mixture," Road Materials and Pavement Design, pp. 1-40, 2020.

[10] J. Choudhary, B. Kumar, and A. Gupta, "Application of waste materials as fillers in bituminous mixes," Waste Management, vol. 78, no. 8, pp. 417-425, 2018.

[11] B. Huang, X. Shu, and X. Chen, "Effects of mineral fillers on hot-mix asphalt laboratory-measured properties," International Journal of Pavement Engineering, vol. 8, no. 1, pp. 1-9, 2007.

[12] A. R. Pasandín, I. Pérez, A. Ramírez, and M. M. Cano, "Moisture damage resistance of hot-mix asphalt made with paper industry wastes as filler," Journal of Cleaner Production, vol. 112, pp. 853-862, 2016.

[13] H. Zhang, H. Li, Y. Zhang, D. Wang, J. Harvey, and H. Wang, "Performance enhancement of porous asphalt pavement using red mud as alternative filler," Construction and Building Materials, vol. 160, pp. 707-713, 2018.

[14] A. Ameli, R. Babagoli, F. Jalali, and M. Khabooshani, "Investigating the influence of replacing two biomass ashes with conventional filler on high and intermediate temperature performance of mastic and mixture," Advances in Civil Engineering Materials, vol. 9, no. 1, pp. 169-194, 2020.

[15] M. Arabani, S. A. Tahami, and M. Taghipoor, "Laboratory investigation of hot mix asphalt containing waste materials," Road Materials and Pavement Design, vol. 18, no. 3, pp. 713-729, 2017.

[16] S. Chandra and R. Choudhary, "Performance characteristics of bituminous concrete with industrial wastes as filler," Journal of Materials in Civil Engineering, vol. 10, 2013.

[17] V. Sharma, S. Chandra, and R. Choudhary, "Characterization of fly ash bituminous concrete mixes," Journal of Materials in Civil Engineering, vol. 22, no. 12, pp. 1209-1216, 2010.

[18] R. C. West and R. S. James, "Evaluation of a lime kiln dust as a mineral filler for stone matrix asphalt," Transportation Research Board, vol. 750, pp. 1-18, 2006.

[19] Iea, "International energy agency tracking industrial energy efficiency and $\mathrm{Co}_{2}$ emissions," 2007, http://www.iea. org/publications/freepublications/publication/tracking_ emissions.pdf.

[20] J. Choudhary, B. Kumar, and A. Gupta, "Laboratory evaluation on recycling waste industrial glass powder as mineral filler in hot mix asphalt," in Proceedings of the Civil
Engineering Conference-Innovation for Sustainability, pp. 352-359, Hamirpur, India, July 2016.

[21] X. Gao, Q. Yu, X. S. Li, and Y. Yuan, "Assessing the modification efficiency of waste glass powder in hydraulic construction materials," Construction and Building Materials, vol. 263, Article ID 120111, 2020.

[22] K. Bisht, K. I. S. A. Kabeer, and P. V. Ramana, "Gainful utilization of waste glass for production of sulphuric acid resistance concrete," Construction and Building Materials, vol. 235, Article ID 117486, 2020.

[23] R. Xiao, P. Polaczyk, M. Zhang et al., "Evaluation of glass powder-based geopolymer stabilized road bases containing recycled waste glass aggregate," Transportation Research Record: Journal of the Transportation Research Board, vol. 2674, no. 1, pp. 22-32, 2020.

[24] Y. Zhang, R. Xiao, X. Jiang, W. Li, X. Zhu, and B. Huang, "Effect of particle size and curing temperature on mechanical and microstructural properties of waste glass-slag-based and waste glass-fly ash-based geopolymers," Journal of Cleaner Production, vol. 273, Article ID 122970, 2020.

[25] S. Zhao, B. Liu, Y. Ding et al., "Study on glass-ceramics made from MSWI fly ash, pickling sludge and waste glass by onestep process," Journal of Cleaner Production, vol. 271, Article ID 122674, 2020.

[26] H. H. Jony, I. Y. Jahad, and M. F. Al-Rubaie, "The effect of using glass powder filler on hot asphalt concrete mixtures properties," Engineering and Technology Journal, vol. 29, no. 1, pp. 44-57, 2011.

[27] M. Saltan, B. Öksüz, and V. E. Uz, "Use of glass waste as mineral filler in hot mix asphalt," Science and Engineering of Composite Materials, vol. 22, no. 3, pp. 271-277, 2015.

[28] A. Simone, F. Mazzotta, S. Eskandarsefat et al., "Experimental application of waste glass powder filler in recycled densegraded asphalt mixtures," Road Materials and Pavement Design, vol. 20, pp. 1-16, 2017.

[29] J. Choudhary, B. Kumar, and A. Gupta, "Effect of filler on the bitumen-aggregate adhesion in asphalt mix," International Journal of Pavement Engineering, vol. 21, no. 12, pp. 14821490, 2020.

[30] J. Choudhary, B. Kumar, and A. Gupta, "Evaluation of engineering, economic and environmental suitability of waste filler incorporated asphalt mixes and pavements," Road Materials and Pavement Design, vol. 22, pp. 1-17, 2021.

[31] H. Khani Sanij, P. Afkhamy Meybodi, M. Amiri Hormozaky, S. H. Hosseini, and M. Olazar, "Evaluation of performance and moisture sensitivity of glass-containing warm mix asphalt modified with zycothermTM as an anti-stripping additive," Construction and Building Materials, vol. 197, pp. 185-194, 2019.

[32] J. Choudhary, B. Kumar, and A. Gupta, "Potential utilization of construction wastes in asphalt pavements as fillers using ranking framework," Construction and Building Materials, vol. 277, Article ID 122262, 2021.

[33] D. Lesueur, J. Petit, and H.-J. Ritter, "The mechanisms of hydrated lime modification of asphalt mixtures: a state-of-theart review," Road Materials and Pavement Design, vol. 14, no. 1, pp. 1-16, 2013.

[34] É. Lachance-Tremblay, M. Vaillancourt, D. Perraton, and H. Di Benedetto, "Linear viscoelastic (LVE) properties of asphalt mixtures with different glass aggregates and hydrated lime content," International Journal of Pavement Engineering, vol. 21, no. 10, pp. 1170-1179, 2020.

[35] S. Raschia, S. Badeli, A. Carter, A. Graziani, and D. Perraton, "recycled glass filler in cold recycled materials treated with 
bituminous emulsion," in Proceedings of the 97th Annual Conference Of Transportation Research Board, Washington, DC, USA, January 2018.

[36] Asphalt Institute, Mix Design Methods for Asphalt Concrete and Other Hot-Mix Types: Manual Series No. 2 (MS-2), Asphalt Institute, Lexington, MV, USA, 6th edition, 1997.

[37] Irc 37, Guidelines for the Design of Flexible Pavements, $4^{\text {th }}$ Revision, Indian Roads Congress, New Delhi, India, 2018.

[38] Astm D854-14, Standard Test Methods for Specific Gravity of Soil Solids by Water Pycnometer, ASTM, West Conshohocken, PA, USA, 2014.

[39] Napa (National Asphalt Pavement Association), Evaluation of Baghouse Fines For Hot Mix Asphalt.Information Series, Napa (National Asphalt Pavement Association), Lanham, MD, USA, 1999.

[40] En 933-9, Tests for Geometrical Properties Of Aggregates-Part 9-Assessment Of Fines Methylene Blue Test, En 933-9, Brussels, Belgium, 1999.

[41] J. T. G. E42, Test Methods of Aggregate for Highway Engineering Research, Institute of Highway Ministry of Transport, Beijing, China, 2005, (in Chinese).

[42] Asphalt Institute, Mix Design Methods for Asphalt Concrete and Other Hot-Mix Types: Manual Series No. 2 (MS-2), Asphalt Institute, Lexington, KY, USA, 7th edition, 2014.

[43] Bs 598-111, Sampling and Examination of Bituminous Mixtures for Roads and Other Paved Areas Part 111: Method for Determination of Resistance to Permanent Deformation of Bituminous Mixtures Subject to Unconfined Uniaxial Loading, BSI Group, London, UK, 1995.

[44] D. W. Christensen and R. F. Bonaquist, Evaluation of Indirect Tensile Test (Idt) Procedures For Low-emperature Performance Of Hot Mix Asphalt, vol. 530, Transportation Research Board, Washington, DC, USA, 2004.

[45] Astm D6931-12, Indirect Tensile (IDT) Strength For Bituminous Mixtures, ASTM, West Conshohocken, PA, USA, 2012.

[46] W. Si, N. Li, B. Ma, Y.-x. Tian, and X.-y. Zhou, "Temperature response to tensile characteristics of the hot asphalt mixtures," KSCE Journal of Civil Engineering, vol. 20, no. 4, pp. 13361346, 2016.

[47] M. T. Nguyen, H. J. Lee, and J. Baek, "Fatigue analysis of asphalt concrete under indirect tensile mode of loading using crack images," Journal of Testing and Evaluation, vol. 41, no. 1, pp. 148-158, 2013.

[48] P. Cui, S. Wu, Y. Xiao, F. Wang, and F. Wang, "Quantitative evaluation of active based adhesion in Aggregate-Asphalt by digital image analysis," Journal of Adhesion Science and Technology, vol. 33, pp. 1-14, 2019.

[49] A. R. Pasandín and I. Pérez, "The influence of the mineral filler on the adhesion between aggregates and bitumen," International Journal of Adhesion and Adhesives, vol. 58, pp. 53-58, 2015.

[50] Astm D3625-12, Standard Practice For Effect Of Water On Bituminous Coated Aggregate Using Boiling Water, ASTM, West Conshohocken, PA, USA, 2005.

[51] Aashto, Resistance of Compacted Bituminous Mixture to Moisture-Induced Damage, Aashto, Washington, DC, USA, 1989.

[52] Nlt-352/86, Caracterización De Las Mezclas Bituminosas Abiertas Por Medio Delensayo Cántabro De Pérdida Por Desgaste, Nlt-352/86, Madrid, Spain, 1986.

[53] Astm D4123-82, Standard Test Method for Indirect Tension Test for Resilient Modulus of Bituminous Mixtures, ASTM, West Conshohocken, PA, USA, 1995.
[54] A. Modarres and P. Alinia Bengar, "Investigating the indirect tensile stiffness, toughness and fatigue life of hot mix asphalt containing copper slag powder," International Journal of Pavement Engineering, vol. 20, no. 8, pp. 977-985, 2019.

[55] CPWD (Central Public Works Department), Delhi Schedule of Rates-Vol. 1, CPWD, New Delhi, India, 2018.

[56] P. Forster, V. Ramaswamy, P. Artaxo et al., "Changes in atmospheric constituents and in radiative forcing." Chapter 2," in Climate Change 2007. The Physical Science Basis, IAEA, Vienna, Austria, 2007.

[57] F. Gschösser, H. Wallbaum, and M. E. Boesch, "Life-cycle assessment of the production of swiss road materials," Journal of Materials in Civil Engineering, vol. 24, no. 2, pp. 168-176, 2012.

[58] J. Choudhary, B. Kumar, and A. Gupta, "Feasible utilization of waste limestone sludge as filler in bituminous concrete," Construction and Building Materials, vol. 239, Article ID 117781, 2020.

[59] S. R. M. Fernandes, H. M. R. D. Silva, and J. R. M. Oliveira, "Carbon dioxide emissions and heavy metal contamination analysis of stone mastic asphalt mixtures produced with high rates of different waste materials," Journal of Cleaner Production, vol. 226, pp. 463-470, 2019.

[60] S. Sreedhar, P. Jichkar, and K. P. Biligiri, "Investigation of carbon footprints of highway construction materials in India," Transportation Research Procedia, vol. 17, pp. 291-300, 2016.

[61] P. White, J. S. Golden, K. P. Biligiri, and K. Kaloush, "Modeling climate change impacts of pavement production and construction," Resources, Conservation and Recycling, vol. 54, no. 11, pp. 776-782, 2010.

[62] D. Hall, Waste Management in Europe: Framework, Trends and Issues, European Federation of Public Service Unions, London, UK, 2010.

[63] U. Bagampadde, U. Isacsson, and B. M. Kiggundu, "Classical and contemporary aspects of stripping in bituminous mixes," Road Materials and Pavement Design, vol. 5, no. 1, pp. 7-43, 2004.

[64] H. Akbulut, C. Gürer, S. Çetin, and A. Elmacı, "Investigation of using granite sludge as filler in bituminous hot mixtures," Construction and Building Materials, vol. 36, pp. 430-436, 2012.

[65] A. Habibnejad Korayem, H. Ziari, M. Hajiloo, and A. Moniri, "Rutting and fatigue performance of asphalt mixtures containing amorphous carbon as filler and binder modifier," Construction and Building Materials, vol. 188, pp. 905-914, 2018.

[66] C. W. Jenks, C. F. Jencks, E. T. Harrigan, M. Adcock, E. P. Delaney, and H. Freer, NCHRP Report 673: A Manual for Design of Hot Mix Asphalt with Commentary, Transportation Research Board, Washington, DC, USA, 2011.

[67] A. Diab and M. Enieb, "Investigating influence of mineral filler at asphalt mixture and mastic scales," International Journal of Pavement Research and Technology, vol. 11, no. 3, pp. 213-224, 2018.

[68] A. Modarres, M. Rahmanzadeh, and P. Ayar, "Effect of coal waste powder in hot mix asphalt compared to conventional fillers: mix mechanical properties and environmental impacts," Journal of Cleaner Production, vol. 91, pp. 262-268, 2015.

[69] A. G. Evans, "The strength of brittle materials containing second phase dispersions," Philosophical Magazine, vol. 26, no. 6, pp. 1327-1344, 1972.

[70] B. J. Smith and S. A. M. Hesp, "Crack pinning in asphalt mastic and concrete: regular fatigue studies," Transportation 
Research Record: Journal of the Transportation Research Board, vol. 1728, no. 1, pp. 75-81, 2000.

[71] K. Sobolev, I. Flores Vivian, R. Saha, N. M. Wasiuddin, and N. E. Saltibus, "The effect of fly ash on the rheological properties of bituminous materials," Fuel, vol. 116, pp. 471477, 2014.

[72] C. L. Monismith, S. C. S. Tangella, J. Craus, and J. A. Deacon, "Summary report on fatigue response of asphalt mixtures," Report TM-UCB-A-003A-89-3, University of California Berkley, Berkeley, CA, USA, 1990.

[73] B. J. Smith, "Low-temperature and dynamic fatigue toughening mechanisms in asphalt mastics and mixtures," Postgraduate Dissertation, Queen's University, Kingston, Canada, 2001.

[74] J. Choudhary, B. Kumar, and A. Gupta, "Analysis and comparison of asphalt mixes containing waste fillers using a novel ranking methodology," Journal of Materials in Civil Engineering, vol. 32, no. 5, Article ID 04020064, 2020c.

[75] V. Antunes, A. C. Freire, L. Quaresma, and R. Micaelo, "Influence of the geometrical and physical properties of filler in the filler-bitumen interaction," Construction and Building Materials, vol. 76, pp. 322-329, 2015.

[76] D. N. Little and D. R. Jones, "Chemical and mechanical mechanisms of moisture damage in hot mix asphalt pavements," in Proceedings of the National Seminar in Moisture Sensitivity, San Diego, CA, USA, February 2003.

[77] A. Modarres and M. Rahmanzadeh, "Application of coal waste powder as filler in hot mix asphalt," Construction and Building Materials, vol. 66, pp. 476-483, 2014.

[78] M. Kumari, G. D. R. N. Ransinchung, and S. Singh, “A laboratory investigation on dense bituminous macadam containing different fractions of coarse and fine RAP." Construction and Building Materials, vol. 191, pp. 655-666, 2018. 